\title{
Komparace vybavenosti žáků 9. tříd klíčovými kompetencemi $k$ učení a řešení problémů
}

\section{Comparison of Key Competency Endowment for Learning and Problem Solving in Pupils of the $9^{\text {th }}$ Grade at Elementary Schools}

\author{
Šárka Maleňáková
}

Fakulta sportovních studií Masarykovy univerzity, Brno

\begin{abstract}
Abstrakt:
Příspěvek se zabývá otázkou, zda nová školská reforma přinesla kvalitněǰ̌sí a efektivnější vzdělávací proces pro žáky podílejicí se na rozvoji životních dovedností (klíčových kompetencí), které jsou pro dnešní dobu rozhodující. Srovnává výsledky výchovně-vzdělávacího procesu v oblasti kličových kompetencí k učení a řšsení problémů u 2 studijnich programů na základních školách, jdoucích v návaznosti těsně za sebou - programu „Základní škola“ a „Rámcově vzdělávací program pro základní vzděláváni“, respektive „Školní vzdělávací program“. Výzkum proběhl v roce 2009, kdy v posledním 9. ročníku byli žáci vyučování podle končicího vzdělávacího programu Základní škola a ve 14 pilotnich školách po celé ČR se realizovala a ověrovala čtvrtým rokem výuka podle vlastních školních vzdělávacích programủ. Pro srovnání vzdèlávacích programů byla použita empirická metoda dotazování v podobě nestandardizovaného dotazníku. Podkladem pro jeho tvorbu se stal dotazník ke kličovým dovednostem, vypracovaný a poskytnutý pro výzkumné a vědecké účely společností SCIO. Testování rozdílů mezi programy v jednotlivých položkách bylo provedeno Pearsonovým chí-kvadrát testem pro kontingenční tabulku. Výsledky ukázaly nevýznamné rozdíly u jednotlivých položek dotazníku, tudiž školní vzdělávací programy, pokud mají splňovat očekávané cíle, musí projít ještě dlouhou cestou pedagogické evaluace. V závěru př́spěvku je vyhodnocena současná problematika zavádèní RVP ZV do škol a jsou navrženy doporučení pro učitele na školách a rovněž pro práci se studenty učitelství na půdě vysoké školy.
\end{abstract}

\begin{abstract}
:
The article deals with the question whether the new reform of education will bring a better and more effective learning process for pupils involved in the development of life skills (key competencies) which are critical these days. The author compares the results of the education process in the field of key competencies included in two education programmes at elementary schools following in close succession - the "Elementary School Programme" and "General Education Programme for Basic Education" and/or "The School Education Programme". The research was conducted in the year 2009 when the last 9 th grade pupils were instructed according to the Primary School Programme while 14 pilot schools throughout the Czech Republic implemented and tested the fourth year of teaching according to their own education programmes. For the comparison of the above mentioned education programmes an empirical method of non-standardized questionnaire was selected. The non-standardized questionnaire was based on a research and scientific Key Competencies Questionnaire supplied by the SCIO organization. Testing the differences between the programmes in particular items was carried out using the Pearson's chi-square test of contingency tables. Results showed insignificant differences in the respective questionnaire items, therefore, education programmes must pass through a long evaluation and assessment process to meet expected targets. The final section of the article is focused on the assessment of problems with introducing the General Education Programme for Basic Education to school syllables. The author presents recommendations for teachers at elementary schools and for academic staff preparing future teachers at universities.
\end{abstract}

Klíčová slova: Rámcově vzdělávací program, školní vzdělávací program, klíčové kompetence $k$ učení a řešení problémů, pilotní školy, kontrolní školy 
Keywords: General education programme, school education programme, key competencies for learning and problem solving, pilot schools, monitored schools

\section{Úvod}

Od 1. 9. 2007 probíhá v České republice postupná reforma školství od mateřských škol až po střední. Hlavní novinkou, kterou reforma přináší, je změna pohledu na požadované cíle vzdělávání. Hlavním cílem vzdělávání by mělo být osvojení takzvaných klíčových kompetencí. Tímto termínem jsou označovány schopnosti a dovednosti uplatnitelné $\mathrm{v}$ praktickém životě, jako třeba umět spolupracovat ve skupině, umět vyjádřit a zastávat vlastní názor a podobně. Zásadní cíl reformy by se dal shrnout do sdělení, že žáci by toho měli více umět, namísto znát.

Jak je uvedeno v Dlouhodobém záměru vzdělávání a rozvoje vzdělávací soustavy ČR (2007), 21. století přináší nové potřeby člověka a vzdělávací proces se musí tomuto jevu přizpůsobit, připravit mládež na informační explozi, naučit ji orientovat se ve světě techniky, účastnit se aktivně života ve svobodné společnosti, být připraven na řešení praktických situací různého druhu, žít v multikulturní společnosti atd. V nově navrženém dlouhodobém záměru ČR 2007, týkajícím se vzdělávání, byla kurikulární reforma označena za nástroj k modernizaci vzdělávání s důrazem na rozvoj klíčových kompetencí.

Hlavním cílem vzdělání se tedy stává rozvoj těch životních dovedností, které jsou pro dnešní dobu klíčové. Každý žák by si měl odnést do života souhrn klíčových kompetencí, což znamená vyvážený poměr mezi množstvím znalostí a zvládáním dovedností i utvářením postojů. Získáním klíčových kompetencí by se mladí lidé měli lépe uplatnit v konkurenceschopnosti na evropském trhu práce (Rámcový, 2005). V příručce Klíčové kompetence $(2007$, s. 7) se uvádí: „Mít určitou kompetenci znamená, že se dokážeme v určité přirozené situaci přiměřeně orientovat, provádět vhodné činnosti, zaujmout prŕnosný postoj.“

„V etapě základního vzdělávání jsou za klíčové považovány: kompetence k učení; kompetence k řešení problémů; kompetence komunikativní; kompetence sociální a personální; kompetence občanské; kompetence pracovní“ (Rámcový, 205, s. 6). Pro náš výzkum byly vybrány kompetence $\mathrm{k}$ učení a řešení problémů. V rámci těchto kompetencí by žák měl na konci základního vzdělávání využívat efektivní učení a směřovat k celoživotnímu vzdělávání. Měl by umět využívat získané informace i v praktickém životě, na základě propojování znalostí si vytvářet komplexní pohled na svět, vnímat nejrůznější problémové situace, vyhledávat informace $\mathrm{k}$ jejich řešení. Plánovaný způsob řešení by měl obhájit. Dále by měl disponovat samostatností a uvědomovat si zodpovědnost za své rozhodnutí (Rámcový, 2005).

Formální rámec školské reformy je dán přechodem od jednotných osnov pro všechny školy k vytváření rámcových vzdělávacích programů, konkrétně pro základní vzdělávání (RVP ZV), podle nichž si školy tvoří své vlastní jedinečné školní vzdělávací programy pro základní vzdělávání.

Žáci by pro svou práci měli být lépe motivováni, výsledky své práce a spolupráce s ostatními žáky by měly přinášet uspokojení. Žáci by měli mít příležitost ukázat, co umí, v čem se zlepšují, a z toho by mělo vycházet jejich hodnocení.

Připravenost škol na reformu a vlastní úroveň programů je různá. Některé školy promýšlely obsah svých programů více, věnovaly více času a píle tvorbě školních vzdělávacích programů a podařilo se jim zde zakotvit řadu moderních a inovativních prvků, jiné $\mathrm{k}$ tomu budou docházet postupně. Také možnost vzdělávání pedagogických pracovníků byla různá. Zkušenosti ze zahraničí ukazují, že ani v jiných zemích nebyl začátek ideální a první programy stoprocentní. Reforma je dnes na začátku a postupně se bude jistě vyvíjet a vylepšovat, obzvláště budou-li přicházet další pozitivní impulsy.

Cílem výzkumu je zjištění, jaké jsou první výsledky práce s novými školními vzdělávacími programy na základě srovnání úrovně osvojení klíčových kompetencí k učení a řešení problémů u žáků 9 . ročníků na pilotních školách, které ověřovaly vlastní Školní vzdělávací program pro základní vzdělávání (ŠVP ZV) a u žáků, kteří studují podle dobíhajících osnov Základní škola (ZŠ). Výsledkem výzkumu by měla být vědecky podložená studie, která se může stát podkladem pro nikdy nekončící práci na vylepšování kurikulárních dokumentů, pro změnu ve způsobu práce a přístupu k žákům. V neposlední řadě může být také podnětným materiálem pro práci se studenty učitelství na půdě vysoké školy. 


\section{Metodika}

Pro výzkum byl využit kvantitativní výzkum ex-post-facto. Cílem byla komparace působení 2 studijních programů a zjištění výsledků už nastavené reformy na základních školách.

\section{Charakteristika souboru}

Soubor pro výzkum byl vytvořen záměrným výběrem -„,kvótním výběrem“. Byly stanoveny určité kontrolní znaky, podle nichž se výběr orientoval. Výběrového šetření se zúčastnilo celkem 28 škol a 1181 respondentů. Experimentální skupina, která byla vzdělávána nově podle Programu 1 (ŠVP ZV), zahrnovala 578 respondentů ze 14 pilotních škol, z toho bylo 289 chlapců a 289 dívek. Kontrolní skupinu tvořili žáci vzděláváni v dobíhajícím Programu 2 (ZŠ) v počtu 603 respondentů, z toho bylo 278 chlapců a 325 dívek. Všichni respondenti experimentální i kontrolní skupiny byli žáky 9. ročníku. Podařilo se nám do výzkumu zapojit všechny pilotní základní školy z celé ČR, které participovaly na projektu MŠMT ČR pod názvem PILOT Z (ověřování ŠVP ZV v praxi). Kontrolní školy byly vybrány ve stejné lokalitě jako školy pilotní, s obdobnými materiálními podmínkami a počtem žáků, aby nedošlo ke zkreslení výsledů vlivem odlišnosti prostředí.

\section{Metody získávání dat}

Data pro naše výzkumné šetření jsme získali pomocí strukturovaného dotazování. Šlo o jednorázové průřezové šetření, což je dle Hendla (2004) hlavní metodou sociologického výzkumu. V jednom časovém bodu je zkoumán výběr cílové populace. Jak uvádí (Pelikán, 2004), je dotazník explorační metoda používaná v pedagogickém empirickém výzkumu. Doporučuje používat k dosažení výzkumného cíle více metod a technik, ale hovoří o výjimce, kterou mohou tvořit výzkumy, kde je vzorek natolik rozsáhlý, že je potřeba se omezit pouze na použití jediné metody (např. dotazník), což je náš případ (1181 respondentů z 28 škol, rozmístěných po celé ČR).

Dotazník byl vypracovaný a poskytnutý pro výzkumné a vědecké účely společností SCIO. Oddělení studia základních škol nám zaslalo dotazník, který byl určen k použití v rámci projektů KEA a STZŠ v dubnu 2008.

Výzkumná část dotazníku obsahovala proměnné, charakterizující dosaženou úroveň klíčových kompetencí $\mathrm{k}$ učení a řešení problémů u respondentů 9. tříd základní školy (příloha). Dotazník obsahoval uzavřené položky, přičemž každá z nich nabízela čtyři možnosti odpovědí. Byla zvolena škála Likertova typu. Odpovědi byly označeny kódy, které respondenti vyplňovali přímo do formulářủ dotazníků. Dotazník byl zvolen jako výzkumný nástroj s dobrou validitou a reliabilitou (Gavora, 2000).

\section{Statistické metody}

Pro statistické vyhodnocení rozdílů mezi programy $\mathbf{P 1}$ a $\mathbf{P 2}$ v klíčových kompetencích k učení a řešení problémů jsme použili Pearsonův chí-kvadrát test, který můžeme zařadit do neparametrických testů statistické významnosti. Jako hladina statistické významnosti byla zvolena hodnota 0,05 (Hendl, 2004).

Pro zpracování dat byly použity statistické programové balíky:

1) StatSoft, Inc. (2009). STATISTICA (data analysis software system), vision 9.0.

2) Hintze J. (2001), NCSS and PASS, Number Cruncher Statistical Systems, Kaysville, Utah.

\section{Výsledky}

Rozdíly v dosažené úrovni osvojených klíčových kompetencí k učení a řešení problémů u žáků 9. ročníku s Programem P1 a P2 jsou uvedeny bez rozdílu pohlaví a zvlášt u chlapců a dívek.

\section{Odlišnost v úrovni osvojených klíčových kompetencí u chlapců a dívek}

Období pubescence je obdobím velkých fyzických a psychických změn, které se projevují často velmi odlišně u hochů a dívek. Pokusili jsme se zachytit statisticky významnou rozdílnost v odpovědích chlapců a dívek programu P1 a chlapců a dívek programu P2. Z tab. 1 je vidět rozdílnost chlapců od dívek v P1 u 8 položek dotazníku a u P2 u 6 položek z celkového počtu 13. Vzhledem k těmto výsledkům uvádíme 
dále komparaci programů v oblasti dosažené úrovně klíčových kompetencí u všech žáků bez rozdílu pohlaví a zvlášt u chlapců a zvlášt u dívek.

Tab. 1: Statisticky významné rozdíly mezi pohlavím v jednotlivých položkách klíčových kompetencí $\mathrm{k}$ učení a řešení problémů (symbol x označuje rozdíl mezi pohlavím $\mathrm{v}$ dané položce na hladině významnosti 0,05$)$

\begin{tabular}{|c|c|c|c|}
\hline Kompetence & Položka & Program 1 & Program 2 \\
\hline \multirow{13}{*}{ 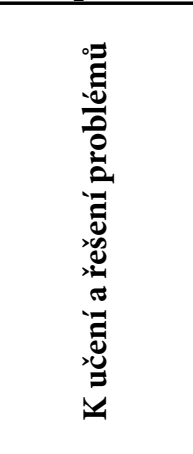 } & 1 & & $\mathrm{X}$ \\
\hline & 2 & $\mathrm{x}$ & \\
\hline & 3 & $\mathrm{X}$ & \\
\hline & 4 & $\mathrm{x}$ & \\
\hline & 5 & $\mathrm{x}$ & $\mathrm{x}$ \\
\hline & 6 & & \\
\hline & 7 & $\mathrm{x}$ & $\mathrm{x}$ \\
\hline & 8 & & $\mathrm{x}$ \\
\hline & 9 & & \\
\hline & 10 & & \\
\hline & 11 & $\mathrm{x}$ & $\mathrm{x}$ \\
\hline & 12 & $\mathrm{x}$ & \\
\hline & 13 & $\mathrm{X}$ & $\mathrm{X}$ \\
\hline
\end{tabular}

\section{Komparace dosažené úrovně klíčových kompetencí (KK) $\mathrm{k}$ učení a řešení problémů}

Legenda:

Položky dotazníku 1-13 jsou součástí prŕlohy.

Kódy odpovědí mají následující význam:

Otázky 1 až 8: $\quad 0$ - rozhodně nesouhlasím, 1 - spíše nesouhlasím, 2 - spíše souhlasím,

3 - rozhodně souhlasím;

Otázky 9, 10: $\quad 0$-nikdy nebo téměř nikdy, $1-$ jen v některých hodinách, 2 - ve většině hodin, 3 - každou hodinu

Otázky 11 až 13: 0 - méně často, 1 - zhruba $1 \times$ za měsíc, 2 - 1× týdně až $1 \times$ za 14 dní, 3 - téměř každý den.

\section{Bez rozdílu pohlaví}

Pro komparaci odpovědí, týkajících se dosažené úrovně KK k učení a řešení problémů u všech žáků, uvádíme v tab. 2 relativní četnosti u staticky významných položek a hladinu významnosti chí-kvadrát testu.

Tab. 2: Relativní četnost u statisticky významných položek KK $\mathrm{k}$ učení a řešení problémů pro programy 1 a 2 bez rozdílu pohlaví

\begin{tabular}{|c|c|c|c|c|c|c|}
\hline \multirow{2}{*}{$\begin{array}{c}\text { POLOŽKY } \\
\text { DOTAZNÍKU }\end{array}$} & \multirow{2}{*}{ PROGRAM } & \multicolumn{4}{|c|}{ KODY (RELATIVNÍ ČETNOST \%) } & \multirow{2}{*}{$\begin{array}{l}\text { Hladina významnosti } \\
\text { chí-kvadrát testu }\end{array}$} \\
\hline & & $\mathbf{0}$ & 1 & 2 & 3 & \\
\hline \multirow{2}{*}{6} & $\mathbf{P 1}$ & 2,8 & 11,9 & 20,2 & 65,1 & \multirow[t]{2}{*}{$p=0,009$} \\
\hline & $\mathbf{P 2}$ & 1,5 & 7,2 & 24,1 & 67,2 & \\
\hline \multirow{2}{*}{8} & P1 & 27,8 & 32,1 & 31,4 & 8,8 & \multirow{2}{*}{$\mathrm{p}=\mathbf{0 , 0 0 1}$} \\
\hline & $\mathbf{P 2}$ & 23,9 & 42,5 & 23,9 & 9,6 & \\
\hline \multirow{2}{*}{9} & P1 & 6,7 & 28,6 & 42,7 & 22,0 & \multirow{2}{*}{$p=0,021$} \\
\hline & $\mathbf{P 2}$ & 10,8 & 34,7 & 38,4 & 16,1 & \\
\hline \multirow{2}{*}{13} & P1 & 21,8 & 16,8 & 26,1 & 35,4 & \multirow{2}{*}{$p=0,001$} \\
\hline & P2 & 15,8 & 14,5 & 30,1 & 39,6 & \\
\hline
\end{tabular}


Položka 6: Procentuálně více respondentů $\mathrm{P} 2$ než respondentů P1 ví, proč je pro ně pohybová aktivita důležitá. Procentuálně více respondentů P1 odpovědělo záporně.

Položka 8: Pokud KK k učení „rozklíčujeme“, pak žák operuje s obecně užívanými termíny, znaky a symboly, uvádí věci do souvislostí. S položenou otázkou, obsahující základní a velmi jednoduchý názvoslovný popis cviků, si neví rady více respondentů P2 (66,45 \% vs. 59,83 \%), zatímco souhlas vyslovilo více resp. P1 (40,17 \% vs. 33,55\%).

Položka 9: Součástí výchovně-vzdělávací strategie v oblasti KK k učení je snaha vést žáky k aktivnímu podílu ve všech fázích činností, na plánování, přípravě, realizaci a také hodnocení. Učitel musí žáky $\mathrm{k}$ této činnosti vést. Výsledky ukazují, že zájem o pokrok projevuje učitel v každé nebo většině hodin častěji v P1 než v P2, zatímco jen v některých hodinách či téměř nikdy projevuje učitel zájem o pokrok častěji v P2.

Položka 13: KK k učení a řešení problémů lze rozvíjet na základě práce s informacemi z různých zdrojů. Vztah ke sportu se projevuje i zájmem o mediální informace. Více respondentů P2 uvádí, že sleduje sport v TV téměř každý den nebo minimálně $1 \times$ za 14 dnů. Více respondentů P1 naopak uvádí, že sledují sport v TV maximálně $1 \times$ za měsíc nebo i méně.

\section{U chlapců}

Pro komparaci výsledků odpovědí, týkajících se dosažené úrovně KK k učení a řešení problémů, uvádíme v tab. 3 relativní četnosti u statisticky významných položek a hladinu významnosti chí-kvadrát testu.

Tab. 3: Relativní četnosti u statisticky významných položek KK k učení a řešení problémů pro programy 1 a 2 u chlapců

\begin{tabular}{|c|c|c|c|c|c|c|}
\hline \multirow{2}{*}{$\begin{array}{c}\text { POLOŽKY } \\
\text { DOTAZNÍKU }\end{array}$} & \multirow{2}{*}{ PROGRAM } & \multicolumn{4}{|c|}{ KODY (RELATIVNÍ ČETNOST \%) } & \multirow{2}{*}{$\begin{array}{l}\text { Hladina významnosti } \\
\text { chí-kvadrát testu }\end{array}$} \\
\hline & & $\mathbf{0}$ & 1 & 2 & 3 & \\
\hline \multirow{2}{*}{7} & P1 & 8 & 19,7 & 41,2 & 31,1 & \multirow{2}{*}{$\mathrm{p}=\mathbf{0 , 0 3 0}$} \\
\hline & P2 & 2,5 & 2,5 & 41 & 35 & \\
\hline \multirow{2}{*}{8} & P1 & 26,7 & 33,7 & 30,2 & 9,4 & \multirow{2}{*}{$p=0,020$} \\
\hline & P2 & 27,1 & 39 & 19,9 & 14,1 & \\
\hline \multirow{2}{*}{9} & P1 & 7,3 & 30,5 & 42,9 & 19,4 & \multirow{2}{*}{$p=0,022$} \\
\hline & $\mathbf{P 2}$ & 13,7 & 34,9 & 34,2 & 17,3 & \\
\hline \multirow{2}{*}{10} & P1 & 28,4 & 39,8 & 19,7 & 12,1 & \multirow{2}{*}{$p=0,010$} \\
\hline & P2 & 37,2 & 42,6 & 11,6 & 8,7 & \\
\hline
\end{tabular}

Položka 7: Při rozvíjení KK k učení a řešení problému jsou žáci vedeni k samostatnému organizování akcí, podněcování tvořivosti, dostávají možnost zažít úspěch, ve výuce jsou vedeni $\mathrm{k}$ řešení problémových situací, plánování a hodnocení. Výsledky ukazují, že žáci P2 vykazují lepší znalosti pravidel a schopnosti organizace, vedení a řízení hry. Naopak více žáků P1 tvrdí, že by se vůbec nedokázalo postavit do role rozhodčího pro neznalost práv a povinností hráčů.

Položka 8: Propojenost otázky 8 s KK je vysvětlena v položce 8 (bez rozdílu pohlaví). S položenou otázkou, obsahující základní a velmi jednoduchý názvoslovný popis cviků, si neví rady nebo spíše neví rady procentuelně víc respondentů $\mathrm{P} 2$, rovněž názvoslovnému popisu určitě rozumí procentuelně víc žáků P2. Velký rozdíl (30,2 \% vs. 19,9 \%) ve prospěch P1 se vyskytl v odpovědi „spíš dokázal“.

Položka 9: Propojenost otázky $9 \mathrm{~s}$ KK je vysvětlena v položce 9 (bez rozdílu pohlaví). Výsledky ukazují, že zájem o pokrok v tělesné výchově chlapců projevuje učitel v každé nebo většině hodin procentuelně více v P1 než v P2, zatímco více chlapců P2 než P1 uvádí, že učitel v tělesné výchově projevuje zájem o pokrok jen $\mathrm{v}$ některých hodinách či téměř nikdy. 
Položka 10: Pro rozvoj KK k učení je žákům umožněno realizovat vlastní nápady, je podněcována jejich tvořivost. Žák disponující KK $\mathrm{k}$ řešení problémů využívá získané vědomosti a dovednosti $\mathrm{k}$ objevování různých variant řešení, samostatně řeší problém, volí vhodné způsoby řešení, ověřuje prakticky správnost řešení problémů a osvědčené postupy aplikuje při řešení obdobných nebo nových problémových situací. Učitel jako tvůrce výchovně vzdělávacího procesu musí záměrně navozovat situace pro rozvoj KK. Procentuelně více probandů P1 uvádí, že učitel zadává samostatnou práci každou hodinu nebo ve většině hodin. Velké procento probandů (P1 - 28,4 \%, P2 - 37,2 \%) uvádí, že učitel žáky nenechává pracovat samostatně nikdy nebo téměř nikdy. Tento výsledek si vysvětlujeme množstvím různých učitelů, kteři se podílejí na výuce tělesné výchovy, a různým přístupem k výuce.

\section{U dívek}

Pro komparaci výsledků odpovědí, týkajících se dosažené úrovně KK k učení a řešení problémů, uvádíme v tab. 4 relativní četnosti u staticky významných položek a hladinu významnosti chí-kvadrát testu.

Tab. 4: Relativní četnosti u statisticky významných položek KK k učení a řešení problémů pro programy 1 a 2 u dívek

\begin{tabular}{|c|c|c|c|c|c|c|}
\hline \multirow{2}{*}{$\begin{array}{c}\text { POLOŽKY } \\
\text { DOTAZNÍKU }\end{array}$} & \multirow{2}{*}{ PROGRAM } & \multicolumn{4}{|c|}{ KODY (RELATIVNÍ ČETNOST \%) } & \multirow{2}{*}{$\begin{array}{c}\text { Hladina významnosti } \\
\text { chí-kvadrát testu }\end{array}$} \\
\hline & & $\mathbf{0}$ & 1 & 2 & 3 & \\
\hline \multirow{2}{*}{2} & P1 & 9,7 & 41,9 & 35,6 & 12,8 & \multirow{2}{*}{$p=0,045$} \\
\hline & $\mathbf{P 2}$ & 10,8 & 31,5 & 45,1 & 12,7 & \\
\hline \multirow{2}{*}{6} & P1 & 1,7 & 12,5 & 21,9 & 63,9 & \multirow{2}{*}{$p=0,038$} \\
\hline & $\mathbf{P 2}$ & 0,9 & 6,2 & 22,8 & 70,2 & \\
\hline \multirow{2}{*}{7} & P1 & 7,3 & 30,1 & 48,4 & 14,2 & \multirow{2}{*}{$\mathrm{p}=\mathbf{0 , 0 5 0}$} \\
\hline & P2 & 7,7 & 31,7 & 39,1 & 21,5 & \\
\hline \multirow{2}{*}{8} & P1 & 28,7 & 30,4 & 32,9 & 8,0 & \multirow{2}{*}{$p=0,002$} \\
\hline & P2 & 21,2 & 45,5 & 27,4 & 5,8 & \\
\hline \multirow{2}{*}{9} & P1 & 5,9 & 27,0 & 42,2 & 24,9 & \multirow{2}{*}{$p=0,009$} \\
\hline & P2 & 8,3 & 34,6 & 42,0 & 15,1 & \\
\hline \multirow{2}{*}{13} & P1 & 25,0 & 20,5 & 30,6 & 24,0 & \multirow{2}{*}{$\mathrm{p}=\mathbf{0 , 0 4 3}$} \\
\hline & $\mathbf{P} 2$ & 17,5 & 16,9 & 36,3 & 29,2 & \\
\hline
\end{tabular}

Položka 2: Žák, který dosahuje patřičné úrovně KK k učení, tř́ídí informace a na základě jejich pochopení, propojení a systematizace je efektivně dokáže využít v procesu učení. Zajímá se o smysl a cíl učení. Procentuelně více probandů $\mathrm{P} 2$ uvádí, že spíše souhlasí s tím, že si předem ujasní smysl učení a uplatnění vědomostí v praxi. Naopak procentuelně více žákyň programu P1 přijímá informace mechanicky bez hlubšího zamyšlení nad jeho smyslem.

Položka 6: Propojenost otázky $6 \mathrm{~s}$ KK je vysvětlena v položce 6 (bez rozdílu pohlaví). Procentuálně více respondentů $\mathrm{P} 2$, než respondentů $\mathrm{P} 1$ ví nebo spíše ví, proč je pro ně pohybová aktivita důležitá. Procentuálně více respondentů $\mathrm{P} 1$ odpovědělo záporně. Obecně pozitivním zjištěním je skutečnost, že velmi malé procento (P1 1,74 \%, P2 0,92\%) neví, proč by mělo provozovat pohybové aktivity. I v tomto př́padě je však více žákyň $\mathrm{P} 1$, které nejsou přesvědčeny o nutnosti pohybových aktivit.

Položka 7: Propojenost otázky 7 s KK je vysvětlena v položce 7 (chlapci). Výsledky ukazují, že žákyně $\mathrm{P} 2$ si více věři ve znalosti pravidel a schopnosti organizace, vedení a řízení hry. Naopak více žákyň P1 tvrdí, že si spíše věří. Procentuální počet těch, kteří uvádějí, že neznají práva a povinnosti hráčů a nedokázali by vést hru jako rozhodčí, je srovnatelný počet.

Položka 8: Propojenost otázky $8 \mathrm{~s} \mathrm{KK}$ je vysvětlena v položce 8 (bez rozdílu pohlaví). S položenou otázkou, obsahující základní a velmi jednoduchý názvoslovný popis cviků, si vủbec neví rady více re- 
spondentů P1, spíše si neví rady procentuelně víc respondentů P2. Názvoslovnému popisu určitě rozumí nebo spíše rozumí procentuelně více žákyň P2. Velký rozdíl (45,54 \% vs. 30,45 \%) ve prospěch P1 se vyskytl v odpovědi „spíš dokázal“.

Položka 9: Propojenost otázky 9 s KK je vysvětlena v položce 9 (bez rozdílu pohlaví). Výsledky ukazují, že zájem o pokroky v tělesné výchově dívek projevuje učitel(ka) v každé nebo většině hodin procentuelně více v P1 než v P2, zatímco více dívek $\mathrm{P} 2$ než P1 uvádí, že učitel(ka) v tělesné výchově projevuje zájem o pokrok jen v některých hodinách či téměř nikdy.

Položka 13: Propojenost otázky 13 s KK je vysvětlena v položce 13 (bez rozdílu pohlaví). Více respondentů dívek P2 uvádí, že sleduje sport v TV téměř každý den nebo minimálně $1 \times$ za 14 dnů. Více respondentů P1 naopak uvádí, že sledují sport v TV maximálně $1 \times$ za měsíc nebo i méně.

\section{Diskuse}

\section{Shrnutí výsledků komparace dosažených klíčových kompetencí k učení a řešení problémů}

Tab. 5: Zjištěná statistická významnost ve prospěch P1/ P2

\begin{tabular}{|c|c|c|c|}
\hline Položky dotazníku & Všichni & Chlapci & Dívky \\
\hline 2 & & & P2 \\
\hline 6 & P2 & & P2 \\
\hline 7 & & P2 & P2 \\
\hline 8 & P1 & P1 & P1 \\
\hline 9 & P1 & P1 & P1 \\
\hline 10 & & P1 & P2 \\
\hline 13 & P2 & & \\
\hline
\end{tabular}

Legenda:

$\mathrm{P} 1=\check{S} \mathrm{VP} Z \mathrm{~V}$

P2 = vzdělávací program ZŠ

Z výsledků šetření (tab. 5) je patrný jistý posun v oblasti práce s novým kurikulem. Dokladem toho jsou výsledky statistické významnosti u otázky 8 , kde žáci musí aplikovat své odborné znalosti v praxi. Zesílil zájem vyučujících o pokroky v pohybových dovednostech a učení u jednotlivců (otázka 9). Tento fakt vychází zřejmě z nutnosti nového hodnocení žáků na základě dosažených KK a hodnocení žákova postupu vpřed. Hoši jsou vedeni více $\mathrm{k}$ samostatnému plnění úkolů, $\mathrm{k}$ problémovému vyučování. Alarmující je výsledek povědomí důležitosti pohybových aktivit. ŠVP ZV by se měly ve větší míře zabývat zdravým životním stylem a důležitostí pohybových aktivit - Výchova ke zdraví. Náš výzkum prokázal větší povědomí u žáků se vzdělávacím programem Základní škola souhrnně bez rozdílu pohlaví a především u dívek. I když se statistická významnost neprokázala při smíšeném hodnocení, chlapci i dívky P2 si více věří ve znalostech povinností a práv hráče, dokázali by se postavit do role rozhodčího. Nabízí se otázka, zda tento jev není způsoben faktem, že žáci se ŠVP ZV si tuto roli častěji vyzkoušeli a setkali se s jistými nedostatky, tudíž si nevěří.

\section{Shrnutí a závěry}

\section{Shrnutí}

Cílem výzkumu bylo zjistit, zda úroveň osvojených klíčových kompetencí k učení a řešení problémů, které se prolínají celým výchovně vzdělávacím procesem a všemi oblastmi vzdělávání a všemi obory a které si žáci odnášejí do života, je vyšší u žáků s vlastním školním vzdělávacím programem, oproti žá- 
kům se vzdělávacím programem Základní škola. Výzkum umožnil také částečně zjistit připravenost škol a pedagogických pracovníků na změny související s kurikulární reformou a schopnost jejich uplatnění v konkrétních podmínkách a pro konkrétní žáky.

Získané výsledky jsou dokladem bud’ žádného nebo malého posunu v úrovni osvojených klíčových kompetencí k učení a řešení problémů, který by školská reforma měla přinést.

Na základě zjištění bylo vyvozeno několik doporučení pro teorii a vlastní praxi.

\section{Závěry pro teorii}

Na úrovni základní školy:

- intenzivní zkvalitňování a prohlubování dalšího vzdělávání pedagogických pracovníků

- doplnit patřičný výcvik škol a učitelů na tvorbu ŠVP a jeho realizaci, učitelé mají k dispozici „Manuál“ (MŠMT, 2005), který pouze motivuje a poskytuje př́klady

- nastavit evaluační formy a evaluačními prostředky pro zjištování úrovně dosažených kompetencí

- očekávané výsledky u žáků nezaměřovat na učivo, ale na činnosti - souvisí s potřebnou změnou pojetí přijímacích zkoušek na stř̌ední školy

- využít nové príležitosti vytvářet kompaktní integrované celky učiva (většina škol s ní nemá zkušenosti, je to problém pro didaktický výzkum)

\section{Na úrovni vysoké školy}

- provést změny v učitelských studijních programech, které budou odpovídat novému pojetí vzdělávání, požadavkům kurikulární reformy

- připravit aprobační strukturu oborů na integraci předmětů a na průřezové prŕístupy

- $\quad$ vytvořit koncepci didaktických inovací $\mathrm{v}$ souvislosti s přijetím RVP

- $\quad \mathrm{v}$ rámci celoživotního vzdělávání doplňovat chybějící kvalifikace již zaměstnaných učitelů

\section{Závěry pro praxi}

Doporučení pro pedagogické pracovniky

- dospět k nutnosti změny v myšlení učitele včetně změny v chápání vlastní profesní role nejen u nezkušených mladých učitelů, kteří nejsou fakultami dostatečně připraveni, ale také u starších učitelů, jež jsou ovlivněni systémem celoživotní práce

- $\quad$ vytvořit ve škole tým, který bude shodně působit na své žáky

- porovnávat výsledky žáků, zapojit se do srovnávacích testů a analyzovat jejich výsledky

- diskutovat se žáky, analyzovat jejich názory na školu

- diskutovat s rodiči o jejich požadavcích na školu

- inspirovat se na prŕkladech dobré praxe

- diskutovat o svých metodách práce navzájem, navštěvovat se vzájemně ve svých hodinách, dále se vzdělávat

- přesunout těžiště svého úsilí od znalostí témat do vyváženého bodu mezi vědomostmi, dovednostmi a postoji.

- učitel by měl ovládat a využívat řadu metod aktivního učení

- napsáním ŠVP nekončit svoji práci, ale naopak nastartovat na základě neustálé reflexe proces změny

\section{Literatura}

Gavora, P. (2000). Úvod do pedagogického výzkumu. Brno, Czechia: Paido.

Hendl, J. (2004). Přehled statistických metod zpracování dat: Analýza a metaanalýza dat. Praha, Czechia: Portál.

Maleňáková, Š. (2011). Analýza a komparace vzdělávacího programu Základní škola a Rámcového vzdělávacího programu pro základní vzdělávání (Doctoral dissertations). Dostupnost z: http://is.muni. cz/th/47091/fsps_d/ 
Ministerstvo školství, mládeže a tělovýchovy (2007). Dlouhodobý záměr vzdělávání a rozvoje vzdělávací soustavy ČR: vládní usnesení č. 535. Dostupné z: http://www.msmt.cz/ministerstvo/ dlouhodoby-zamer-vzdelavani-a-rozvoje-vzdelavaci-soustavy-cr

Pelikán, J. (2004). Základy empirického výzkumu pedagogických jevů. Praha, Czechia: Karolinum.

Výzkumný ústav pedagogický v Praze (2005). Rámcový vzdělávací program pro základní vzdèlávání: (se změnami provedenými k 1. 7. 2007). Dostupné z: http://www.msmt.cz/vzdelavani/ ramcovy-vzdelavaci-program-pro-zakladni-vzdelavani-verze-2007

Výzkumný ústav pedagogický v Praze (2007). Kličové kompetence v základním vzdělávání. Dostupné z: http://www.msmt.cz/vzdelavani/skolskareforma/klicove-kompetence

Př́loha: Výzkumná část dotazníku

Položky ke zjištění dosažené úrovně KK k učení a řešení problémů

Uvažuj, co ses naučil(a) ve škole. Do jaké míry souhlasíšs následujícími větami?

1. Když mi kamarád předvede kotoul vpřed, umím najít nedostatky a poradit mu, jak je odstranit

2. Než se začnu učit např. herní činnosti jednotlivce $\mathrm{v}$ košíkové nebo vyměření rozběhu u skoku do dálky, dopředu si pořádně ujasním, co a proč se to učím

3. Naučit se novou pohybovou dovednost v tělesné výchově a využít ji pro hru, soutěž nebo při rekreaci mě baví

4. Když se něco rozhodnu v tělesné výchově naučit, tak se mi to podaří

5. Na tělesnou výchovu se těším

6. Vím, proč je pro mě pohybová aktivita důležitá

7. V míčových hrách, které jsme v tělesné výchově hráli, znám práva a povinnosti hráče, na základě kterých dokážu vést hru jako rozhodčí

8. Dokázal bys podle následujícího popisu provést cvik? „stoj zánožný levou-předpažit: přednožit-zapažit, váha předklonmo-vzpažit“

\section{Jak často dochází v hodině tělesné výchovy k následujícím situacím?}

9. Učitel(ka) projevuje zájem o pokroky v pohybových dovednostech a učení každého z nás.

10.Pracujete samostatně na nějakém úkolu v rámci TV (např. nácvik gymnastické sestavy, dopomoc spolužákům, práce rozhodčího, organizace turnajů, závodů,...).

\section{Jak často:}

11. Používáš Internet k hledání informací o sportovcích, výsledcích sportovních utkání, informací týkajících se sportu?

12. Přemýšliš o svých pohybových aktivitách, zdravé stravě, optimální tělesné a duševní zátěži?

13. Sleduješ sportovní pořady nebo sportovní zpravodajství v televizi? 